\title{
Philippe Lejeune
}

Université Paris 13

\section{Dziennik: geneza pewnej praktyki piśmiennej}

\begin{abstract}
A Diary: the genesis of a certain writing practice

How can one study the genesis of a text written straightaway which would lose its authenticity value if it were corrected? Such a text is the evidence of a practice, so that transforming it into a work (especially a published one) is likely to impoverish and disfigure it. This article intends to show that if Genetic Criticism has little leeway, it still has room to maneuver: preparatory notes and editing on the same day, intertextual situations (reading notes, correspondence quotations, etc), analysis of the progressive transformations of the diary's rhythms, the diarist's writing about rereading, recopying his journal... Past this point, the diary becomes either an autobiography (a selection or composition of the diary by the author him/herself) where Genetics has ample room to perform, or a publication.
\end{abstract}

Słowa kluczowe: krytyka genetyczna, dziennik

Keywords: genetic criticism, diary

Dziennik może być miej scem, w którym dokonuje się geneza dzieła, co wykazała już Françoise Simonet-Tenant.

Może też być zamierzonym świadkiem procesu narodzin dzieła, książką reżyserską lub kontrolną, co udowodniła z kolei Catherine Viollet. 
W obu wypadkach dziennik jest - zgodnie z terminologią, którą uzna się za stosowną - przedtekstem lub częścią dossier genezy dzieła innego niż on sam. Bierze udział jako czynnik sprawczy i/lub świadek w pracy twórczej, której sam nie jest celem. Nie stanie się zatem przedmiotem analizy z zakresu krytyki genetycznej, nawet jeżeli pytanie o jego powstawanie może się pojawić w takiej analizie. Występuje on w niej bowiem jedynie jako narzędzie.

Czy zatem dziennik jako taki może mieć genezę?

Chciałbym zająć się w tym artykule teoretycznymi implikacjami tego pytania. Niniejsza analiza śledzi tok tej, którą 10 lat temu przeprowadził José-Luis Diaz, szukając odpowiedzi na pytanie: „W jakiej mierze krytyka genetyczna ma zastosowanie w przypadku korespondencji?"'. Jeżeli chodzi o ilustracje i przykłady, odsyłam do wydania albumowego przygotowanego przeze mnie we współpracy z Catherine Bogaert ${ }^{2}$, jeżeli chodzi zaś o teorię - do mojego pierwszego eseju zatytułowanego Genèse du journal ${ }^{3}$.

Postawione wyżej pytanie nie jest jedynie czysto formalne. Podaje w wątpliwość sposób pojmowania dziennika i założenia badań z zakresu krytyki genetycznej, w szczególności kluczowe znaczenie, jakie przypisują one dziełu jako końcowemu efektowi procesu twórczego. Istotnie, dziennik nie jest początkowo ani zasadniczo dziełem literackim: jest praktyką piśmienną, której treść i celowość określa życie autora.

To stwierdzenie może się wydać zbyt upraszczające dla większości czytelników, którzy - o ile sami nie prowadzili dziennika - mają z nim do czynienia głównie właśnie w postaci opublikowanych dzieł, i zwykli postrzegać go jako wstęp do książki lub materiał, na podstawie którego ona powstaje.

Tymczasem dziennik jest przede wszystkim praktyką piśmienną. Z uwagi na charakterystykę tej praktyki trudno analizować dziennik za pomocą narzędzi, którymi tradycyjnie posługuje się krytyka genetyczna skupiająca się na pojęciu dzieła literackiego. Ale trudność nie oznacza niemożliwości. Obie te perspektywy - perspektywa praktyki i perspektywa dzieła - zazębiają się, a obszar wspólny, choć niewielki, jest nad wyraz fascynujący. s. 11-31.

J.-L. Diaz, Quelle génétique pour la correspondance?, „Genesis” 1999, nr 13,

2 Ph. Lejeune, C. Bogaert, Un journal à soi. Histoire d'une pratique, Paris 2003. Napisany przez Lejeune'a Wstęp do tej publikacji został opublikowany w thumaczeniu na język polski; zob. Ph. Lejeune, Dziennik osobisty - wprowadzenie do rozumienia pewnej praktyki; przeł. M. i P. Rodakowie [w:] idem, ,,Drogi zeszycie...”, ,, drogi ekranie”. O dziennikach osobistych, przeł. A. Karpowicz, M. i P. Rodakowie, Warszawa 2010, s. 33-45.

3 Ph. Lejeune, Genèse du journal [w:] idem, Les Brouillons de soi, Paris 1998, s. $317-330$. 


\section{Ograniczenia}

\section{Pierwsze ograniczenie: sposób pracy}

Z chwilą gdy wybija północ, autor nie powinien już modyfikować tego, co wpisał pod datą z dnia, który właśnie upłynął. Każda późniejsza ingerencja (dodawanie tekstu, usuwanie, zmiany w jego układzie, zastępowanie jego fragmentów) sprawi, że to, co napisał, przestanie być dziennikiem, a stanie się autobiografią, czymś, co pozwala kreować na nowo przeszłość w świetle teraźniejszości. Wartość dziennika wiąże się z autentycznością zapisu, a każda późniejsza zmiana stanowi dla tej autentyczności zagrożenie. Dziennik jest wrogiem autobiografii. O ile ta ostatnia bywa ulubionym przedmiotem badań genetycznych, to w wypadku dziennika krytyka genetyczna ma niewielkie pole manewru. Czas na naniesienie ewentualnych poprawek nie przekracza kilku godzin. Dziennik, niczym akwarela, nie znosi retuszu.

\section{Drugie ograniczenie: zakończenie}

Prowadzący dziennik pisze tekst, którego konkluzja nie należy do niego. Posuwa się do przodu niejako na oślep, zmierzając ku nieznanemu zakończeniu i akceptując fakt, że kształt tego ostatniego zależy od niego jedynie częściowo. Taki zarzut wysuwają pod adresem dziennika zwolennicy tradycyjnej estetyki. Wystarczy przywołać słowa Charles'a Dantziga:

W porównaniu z powieścią, sztuką teatralną czy poematem [dzienniki - dop. thum.] mają pewien defekt, którym jest brak zakończenia. Utwór nie może być doskonały, swą własną doskonałością, jeżeli nie ma zakończenia, do którego zmierza: to z perspektywy zakończenia poprawiamy początek i środek, by nadać sens całości ${ }^{4}$.

Możemy oczywiście przyjąć zupełnie inną perspektywę. Odium - słowo to bynajmniej nie jest zbyt mocne w przypadku Dantziga - otaczające dziennik wynika z tego, że jego bezpretensjonalność odsłania pychę pisarza, który tworzy światy, pretendując do roli ich pana i władcy. Dziennik jawi się zatem jako wyrzut sumienia dla literatury. Uzmysławia jej, że kontrola, do której ona pretenduje, pozostaje iluzoryczna. W rzeczywistości bowiem pisarze nie mają ostatniego słowa, umierają, a dzieło żyje. Dziennik akceptuje te granice, codziennie mierzy się z zakończeniem, które mu umyka, odroczone do jutra. Każdy wpis jest pożegnaniem. W gruncie rzeczy dziennik to seria ostatnich słów, ale takich, które przeżywa się jako przedostatnie z nadzieją, że jutro powstaną kolejne. Czy jednak tak będzie? Nie sposób tego przewidzieć, nawet

${ }^{4}$ Ch. Dantzig, Dictionnaire égoïste de littérature française, Paris 2005, s. 418. 
jeżeli można się do tego przygotować. Autorzy tak właśnie często czynią, czego klasycznym przejawem może być fakt, iż zamknąwszy wpis z danego dnia, stawiają, niejako na wszelki wypadek, datę dnia kolejnego.

Tradycyjna estetyka dzieła ma zatem kłopot z formą dziennika. Nie zapominajmy jednak, że kompozycja zorganizowana wokół zakończenia nie jest bynajmniej jedynym rozwiązaniem. Istnieje wszak estetyka fragmentaryczności, powtórzeń czy nawarstwiania się tekstu. Dość wspomnieć, że Michel Leiris marzył o takim procesie pisania, który pomijałby zakończenie, godząc logikę dzieła z nieskończonością, by tak rzecz ująć, dziennika:

Utwór pomyślany w taki sposób, by stanowił autonomiczną całość, w którymkolwiek momencie nie zostałby zakończony przez śmierć. Utwór celowo tworzony jako dzieło prawdopodobnie pośmiertne i ciągła „praca w toku”.

\section{Trzecie ograniczenie: celowość}

Podstawowym celem dziennika nie jest oddziaływanie w zamierzony sposób na czytelnika, ale zapis zdarzeń z życia autora. $Z$ tego powodu bliżej dziennikowi do archiwum niż do utworu literackiego. Oczywiście funkcja dokumentacyjna nie musi być jedyną motywacją przyświecającą piszącemu. Archiwum może się stać materiałem literackim. Ale archiwum różni się tym od literatury, że pełni inną funkcję dla osoby prowadzącej dziennik (w chwili gdy go prowadzi) i tej, która go czyta (sam autor lub inne osoby). Przede wszystkim dziennik nie jest wyłącznie tworem tekstowym, jego treścią i budulcem staje się w takiej samej mierze życie. Jedynie wtórnie może on być postrzegany w kategoriach kreacji tekstowej, przede wszystkim jest bowiem praktyką piśmienną i postawą życiową. W pewnym sensie w procesie pisania „kreacji” podlega osoba prowadząca dziennik. Lektura dziennika nie jest tym samym, co lektura utworu literackiego, jest zagłębianiem się w enigmę, gdzie to, co wprost wypowiedziane, jest zaledwie ułamkiem tego, czego brakuje.

Dwa pierwsze ograniczenia: sposób pracy i brak zakończenia, pozostawiają niewielką wprawdzie, ale realną przestrzeń dla badań z zakresu krytyki genetycznej, nie podają bowiem w wątpliwość tożsamości tego, co czytamy, jako tekstu „tworzonego". Natomiast trzecia kwestia podważa samą istotę krytyki genetycznej. Tekst, który czytamy, okazuje się tylko wskazówką, śladem, pozostałością pewnego procesu, ukierunkowanego na coś zupełnie innego. Należałoby zatem poddać analizie wzajemne przenikanie się pisania i życia, ale to wymagałoby znajomości biografii autora, do czego ślady te zachęcają nas, nie dając jednak narzędzi.

\footnotetext{
5 M. Leiris, Journal 1922-1989, oprac. J. Jamin, Paris 1992, s. 614 (26 września 1966).
} 
Wobec tych trudności dochodzimy do wniosku, że podobnie jak błędem byłoby odkorkowywanie butelki za pomocą otwieracza do puszek, tak samo nie ma sensu rozpatrywać czegoś, co stanowi praktykę piśmienną, w kategoriach dzieła. Chcąc pozostać w ramach krytyki genetycznej, możemy oczywiście oprzeć się na rozróżnieniu między narodzinami dzieła realizującymi z góry założony program a genezą procesu stawania się dzieła. Jednak najprościej będzie rozważać pisanie dziennika jako praktykę piśmienną, co pozwoli nam pominąć kwestie celowości. Nie musimy już wyjaśniać retrospektywnie, jak powstał tekst, który przyjął status dzieła literackiego, możemy po prostu prześledzić dzień po dniu proces pisania, starając się zrozumieć reguły jego funkcjonowania. Logika badań z zakresu krytyki genetycznej znajdzie zastosowanie później, w sytuacji gdy autor lub osoby trzecie będą opracowywać teksty zapisane „naturalnie”, celem nadania im formy książkowej, albo w wypadku gdy piszący dziennik z góry uwzględnia wymogi tej formy.

Pójdźmy dalej. Badania krytyków genetycznych obejmują z reguły analizę narodzin dzieł, które zostały wydane i którym przypisuje się walory literackie uzasadniające podjęty trud sięgania wstecz aż do przedtekstów, nierzadko w formie rękopisów. Od rękopisu do postaci wydrukowanej zachodzi pewna ewolucja, tekst staje się bogatszy. W wypadku dziennika dzieje się odwrotnie, proces ten należałoby rozważać w kategoriach degradacji czy zubożenia. Stwierdzenie to może się wydać brutalne i szokować zwolenników „dzieła”. Forma rękopisu nie jest dla dziennika punktem wyjścia, etapem pośrednim, ale punktem docelowym. Wszystko, co stanie się z nim potem, w szczególności publikacja, będzie zafałszowaniem. Dziennik może budować znaczenie za pomocą większej liczby środków wyrazu niż sam tekst. Rodzaj materiału piśmienniczego, atrament, sposób pisania, układ, dekoracje i ilustracje stanowią część śladów współtworzących świadectwo chwili w takim samym stopniu, w jakim użyte przez autora słowa. Dziennik, do końca XIX wieku dość oszczędny w ilustracje, wzbogacił się najpierw o zdjęcia, potem zaś w drugiej połowie XX wieku o wszystkie materialne wytwory życia, stając się czymś na kształt relikwiarza, kolażu, bazaru czy instalacji. Swego czasu zajmowałem się analizą dziennika, który pewna nastolatka, Claire, prowadziła w latach siedemdziesiątych XX wieku'. Na jego objętość, imponujące osiem zeszytów spisanych w ciągu 2 lat, złożyły się właśnie wszelkiego rodzaju „pamiątki”. Choć wydaje się tak zwyczajny, dziennik współdzieli status dzieła sztuki, jest bowiem w swej formie unikatowy. Natomiast w procesie przygotowania do druku spora część oryginalnego przekazu ginie. Wszystkie wydane dzienniki są do siebie podobne, podczas gdy różnorodność formy i wyglądu rękopisów jest zdumiewająca. Do tego prawie wszystkie wydane dzienniki są wynikiem poczynionych skrótów, dlatego że oryginały były zbyt obszerne, by zmieścić się w jednej książce, albo po to, by poprawić ich rytm lub by ocenzurować

\footnotetext{
6 Ph. Lejeune, Le journal-herbier [w:] idem, Les Brouillons de soi, s. 367-385.
} 
zawartość. Należałoby zatem znaleźć słowo odwrotne do „genezy” na określenie procesu „redukcji”, który pozwala tekstowi powstałemu na podstawie dziennika wejść do obiegu książki. Przywrócenie formie drukowanej postaci oryginalnego rękopisu ma w zasadzie więcej wspólnego z restauracją dzieła sztuki niż z badaniami genetycznymi.

Punktem odniesienia dla badań nad dziennikiem nie powinna być zatem postać wydrukowana, lecz rękopis. Wychodząc od rękopisu i śledząc jego rozwój, możemy przeanalizować powstanie tego, co czytamy i widzimy. Cofając się do rękopisu, możemy ewentualnie zbadać, w jaki sposób to, co czytamy i widzimy, uległo przekształceniom lub deformacji, by móc wejść do uniwersum książki. Które rękopisy analizować? Odpowiedź jest prosta - wszystkie dzienniki w formie rękopisów, niezależnie czy miały szczęście czy też nieszczęście zostać wydrukowane. Badania z zakresu krytyki genetycznej wychodzą zazwyczaj od pojedynczego „dzieła” o uznanych walorach literackich. Badania nad genezą dzienników powinny się opierać na jak najbardziej zróżnicowanej próbce tekstów i uwzględniać jako metodę rozmowę z ich twórcami. Powinny również prowadzić do sformułowania ogólnych stwierdzeń, co rzadko zdarza się w wypadku badań z zakresu krytyki genetycznej. Pytanie tylko, czy rzeczywiście są to jeszcze badania z zakresu krytyki genetycznej. Choć może raczej powinno ono brzmieć następująco: w jaki sposób, opracowując metodę dostosowaną stricte do badanego zjawiska, pozostać w ramach danej dyscypliny? Dziennik wydaje się niejednoznacznym przedmiotem analizy, zasadniczo jest bowiem praktyką piśmienną, czasem jedynie i tylko wtórnie produkcją dzieła literackiego. Do nas należy jak najtrafniejsze dobranie metod spośród tych, którymi dysponujemy.

\section{Etapy}

\section{Śledzenie toku metadyskursu}

Pierwsza myśl, która nasuwa się, gdy zastanawiamy się nad zastosowaniem metod krytyki genetycznej do analizy dzienników, to skupienie się na przypadkach, w których dziennik prezentuje się jako dzieło „zaplanowane”. Dość często autor zaczyna pisanie od postawienia sobie celu i określenia procedur, później zaś, gdzieniegdzie, kontroluje i komentuje sposób realizacji pierwotnych założeń, uskarża się na swoją niekonsekwencję, ocenia wpisy, zmienia reguły gry itp. Wyszukiwanie tego metadyskursu jest z pewnością pierwszym działaniem, które należy podjąć. Prowadzi bowiem zarazem do analizy między- i wewnątrztekstowej. Metadyskurs, który spotykamy zazwyczaj we wstępie, daje wskazówki dotyczące przyjętych wzorów, czy to zaczerpniętych z lektury wydanych dzienników od połowy XIX wieku, czy wcześniej 
z tekstów należących do tradycji religijnej, familijnej bądź też pedagogicznej. Jednak zadeklarowany na początku program nie musi być tym, który w rzeczywistości jest realizowany. Popatrzmy na założenia, jakie przyświecały Pierre'owi-Hyacinthe'owi Azaïsowi (1766-1845):

\section{2 września $1798 \mathrm{r}$.}

Cała ta przestrzeń jeszcze pusta następująca po pierwszej stronie przyjmować będzie i stawiać mi przed oczami wierny ślad wszystkiego, co poruszy mój umysł, przemówi do serca, uwzniośli lub zbruka mą duszę. Surowy cenzor, skrupulatny sędzia, rejestr ów wszystkich spraw mojego życia będzie miał nad najwierniejszym nawet lustrem tę przewagę, że zachowa wszystko, co zostanie mu przedstawione, i odtworzy - bądź to przywołując szczęśliwe wspomnienia, bądź to wywołując ból i żal - dobro, które uczynię, zło, któremu ulegnę. A Ty, dobry Boże, który już dziś czytasz to, co jeszcze nie zostało zapisane, spraw, aby za sprawą moich czynów i dyspozycji mojego serca w Twoich oczach nie zagościło zagniewanie, a jedynie dobroć i pogoda ducha!?

Trudno wyobrazić sobie, by ów konwencjonalny program swoistego rachunku sumienia mógł się przekształcić m.in. w zapis przeżyć miłosnych czy niezwykle bogatego i twórczego życia intelektualnego, miejsce, gdzie niemal sto lat przed Paulem Valérym Azaïs odkrył, że geneza dzieła potrafi być czasem bardziej interesująca niż jej rezultat ${ }^{8}$. Analiza metadyskursu ma więc swoje ograniczenia. Dzienniki mają w pewnym sensie dwóch autorów: prowadzącego dziennik, który nosi się z zamiarem i planuje, oraz życie, nieprzewidywalne, które decyduje. Zmiany, niedokończone wpisy, powtórzenia, niespójności, braki są czasami komentowane przez autora, gdy ów „podejmuje tok pisania”, najczęściej jednak wprawiają w zakłopotanie czytelnika, który - by zrozumieć sens czytanego fragmentu - musi prowadzić pozatekstowe poszukiwania w biografii autora. Oczywiście prawdą jest, zgodnie z obiegowym przekonaniem, że dziennik wyjaśnia w jakiejś mierze życie autora, jednak przede wszystkim sam potrzebuje dopełnienia przez nie. Większości dzienników brakuje spójności i są one pełne niedomówien, do których tylko autor posiada klucz, przynajmniej tak długo, jak sam zachowuje w pamięci kontekst opisanych zdarzeń. Jak zatem badać genezę tekstu, którego sensu w istocie nie kontrolujemy? Metadyskurs sam w sobie, choć wydaje się służyć za przewodnika, potrzebuje objaśnień.

7 Tekst cytowany przez J. Guadeta w jego wydaniu Azaïsa, Des compensations dans les destinées humaines, Paris 1846.

$8 \mathrm{Ph}$. Lejeune, Azaïs et le journal-œuvre, tekst dostępny online na stronie www.autopacte.org [dostęp: 23.06.2019]. 


\section{Geneza dzień po dniu}

Wróćmy do podstawowego budulca dziennika: notatki lub wpisu opatrzonego datą. Wydaje się, że badania z zakresu krytyki genetycznej nie mają w tym wypadku w ogóle zastosowania. W istocie większość prowadzących dziennik pisze bez skreśleń czy poprawek w sposób bardzo regularny. Obserwacja ta i fakt, że dzieje się tak niezależnie, czy mamy do czynienia z uznanym pisarzem czy nie, były jednymi z największych zaskoczeń dla odwiedzających wystawę „Un journal à soi” w 1997 roku. Słowa, pisane każdego dnia na czysto, wydają się układać w zdania bez wysiłku i bez konieczności poprawek, tworząc teksty czasem wręcz doskonałe. Bez żalu, bez pokuty. Jest to oczywiście iluzja: każdy wpis jest wynikiem jakiejś redakcji, nawet jeżeli ta ostatnia odbywa się błyskawicznie i w sposób niepozostawiający śladów, bo dokonuje się w głowie lub ustnie. W rzeczywistości autor zaczyna tworzyć wpis już w ciągu dnia, reagując na to, co ów mu przynosi. Dysponuje w głowie gotowymi schematami, wzorami zdań, całymi akapitami, oczekującymi na treść, która je wypełni. Ma swoje oczekiwania i obsesje, projekty i scenariusze. Niektóre zdarzenia i emocje, dokładnie te, a nie inne, potrafią wzbudzić ów mechanizm, który daje w rezultacie pozornie szybki wpis na papierze. Sam autor, w wielu wypadkach, choć nie stanowi to reguły, nie jest świadomy działania tego mechanizmu. Dlatego wpis to uwiecznienie na papierze tego, co życie zapisało już wcześniej w głowie. W swoim dzienniku Virginia Woolf komentuje żartobliwie problemy, jakie sprawiają jej owe „bruliony w głowie”, gdy zdarzenia dnia codziennego zakłócają możliwość zarządzania nimi:

Popełniłam poważny błąd w założeniach tego dziennika, postanawiając, że będę pisać go po herbacie. Gdy ktoś odwiedza mnie w porze tejże, nie mogę przecież powiedzieć: „Daj mi chwilkę, tylko zapiszę sobie to, co Ciebie dotyczy”. Gdy zaś ów ktoś pójdzie już sobie, jest za późno na pisanie. Tak więc w chwili, gdy układam w głowie myśli i opisy, które powinny znaleźć się na stronie, odczuwam jednocześnie zniechęcenie, bo żadnej nie mam przed sobą; moje myśli rozpraszają się niczym paprochy po podłodze. I naprawdę nie sposób zebrać je z powrotem $\mathrm{W}$ całość ${ }^{10}$.

Kolejny problem to nadmiar ,brulionów ustnych”:

Najpierw jednak chcę przywołać Janet, Desmonda, Katherine Mansfield i Lilian; byli też inni - tak, byli Harry Stephen i Clive. Po każdym pozostała stroniczka komentarzy, bezużytecznych już teraz częściowo z tego powodu, że mam zwyczaj opowiadać o takich wydarzeniach różnym osobom, a opowiadanie pozostawia mi

9 Ph. Lejeune, C. Bogaert, Un journal à soi (ou la passion des journaux intimes), wydanie albumowe, Lyon 1997.

10 V. Woolf, Journal, t. I, trad. par C.-M. Huet, Paris 1981, s. 248 (czwartek 18 maja 1918). 
w umyśle rowek, który usztywnia wspomnienie i stereotypizuje je, przydaje mu pewnej nudy ${ }^{11}$.

Defekt badań z zakresu krytyki genetycznej polega na tym, że definiują one operacje umysłowe na podstawie pozostawionych przez nie śladów: a w wypadku dzienników nie ma takich. Podobnie jak istnieją „ciche” choroby, istnieją ,ciche” genezy. Brulion w głowie powstaje w interakcji „modelu”, czasem świadomie przywoływanego $\mathrm{w}$ chwili poprzedzającej pisanie przez odczytanie ostatnich wpisów, i tego, co „przeżyte” w ciągu dnia. Skreślenia, jeżeli występują, wydają się w mniejszym stopniu oznaką pracy nad tekstem niż błędami transkrypcji tekstu opracowanego w głowie. Dziennik współdzieli z listem ten wymóg czystości i bezbłędności. Może się jednak zdarzyć, że danego dnia autor pracuje nad tym samym wpisem dwa razy. Ale rola tej dwukrotnej pracy jest inna niż w wypadku listu. Brulion listu służy wypracowaniu jego ostatecznej formy, układu i stylu, który pojawi się już w wersji na czysto: celem jest zatem skończony produkt. Brulion dziennika nie dba w takim stopniu o końcowy tekst. Chodzi jedynie o szybkie notatki, sporządzane, gdy autorowi brakuje czasu lub gdy okoliczności uniemożliwiają mu pisanie albo gdy nie ma przy sobie dziennika, albo też istnieje ryzyko, że pamięć zawiodłaby go. Notatki mają być podstawą tekstu właściwego. Mamy więc do czynienia z dwoma różnymi tekstami: jednym skrótowym, drugim - zredagowanym. Przy czym pierwszy, gdy tylko odegra swoją rolę, najprawdopodobniej zostanie zniszczony. Jednym z eksponatów, który pojawił się w ramach wystawy „Un journal à soi”, był dziennik prowadzony w zeszycie szkolnym, a właściwie na jego marginesach. Autorka spisywała tam szybkie notatki, które miała zamiar rozwinąc na wolnych stronach, jednak z braku czasu nigdy tego planu nie zrealizowała ${ }^{12}$. Niektórzy autorzy, by wymienić choćby Louisa Calaferte' $\mathrm{a}^{13}$, piszą jedynie na prawej stronie w zeszycie, zostawiając lewą na późniejsze uzupełnienia, notatki, dokumenty, komentarze. Tworzenie ostatecznego tekstu z wstępnych notatek nie musi się odbywać tego samego dnia. Dzieje się tak zwłaszcza w wypadku dzienników rejestrujących fakty: Ludwik XVI porządkował swoje notatki na koniec miesiąca. Bardzo często autorzy, zarówno ci skrupulatni, jak i niedbali, gromadzą notatki z kilku dni lub tygodni i nadrabiają potem zaległości jednym wpisem.

Jednym z problemów w wypadku dziennika jest zatem kwestia postrzegania granic „teraz”, czasu, po przekroczeniu którego dziennik staje się już autobiografią, a usprawiedliwione skreślenie - rekonstrukcją. To postrzeganie może być bardzo różnorodne, mniej lub bardziej elastyczne. Istnieją dzienniki datowane co do minuty, dla których „teraz” godzinę później jest już prze-

11 Eadem, Chwile wolności. Dziennik 1915-1941, przeł. M. Heydel, Warszawa, 2007, s. 68, wpis z wtorku 28 maja 1918.

12 Un journal à soi. Histoire d'une pratique..., s. 86-87.

13 Un journal à soi (ou la passion des journaux intimes), $\mathrm{nr} 81, \mathrm{~s} .58-59$. 
szłością, w którą nie należy ingerować. Najbardziej spektakularny przypadek, z jakim się zetknąłem, to Philippe de Noircarmes (1747-1821), który podawał minutę początku i końca każdego akapitu i poprawiał go lub uzupełniał jedynie $\mathrm{w}$ formie erraty, również datowanej co do minuty ${ }^{14}$. Ale istnieją również odwrotne przypadki, gdy autor żyje w bliżej nieokreślonym „teraz”, rozciągającym się poza granice dnia czy nawet tygodnia, co daje mu prawo do ingerowania w tekst, który wciąż pozostaje dla niego bieżący.

Co dzieje się z dziennikiem w dobie komputera? Ostatnie badania Ministerstwa Kultury z 2008 roku, dowodzą, że „,74\% diarystów używa zeszytów lub kartek papieru, 18\% komputera, a 8\% obu mediów" ${ }^{15}$. Komputer nie wyparł zatem papieru, który w wypadku dziennika pozostaje głównym materiałem piśmienniczym. Ale dane te nie mówią nic o przeobrażeniach w samej praktyce piśmiennej, jaką jest prowadzenie dziennika. W tym względzie odsyłam do analizy, którą przeprowadziłem w 1998 roku $^{16}$. Komputer wprowadził bowiem istotną innowację: możemy zredagować wpis, nie pozostawiając śladu po zmianach. Autor posługujący się papierem musi od razu napisać gotowy tekst. Udaje mu się to dzięki wprawie i określonemu stylowi pracy, zastanawia się, zanim napisze zdanie i stara się trafić w sedno. Nie może sobie pozwolić na to, by jego kartka nosiła ślady wahania. Skreślenia utrudniałyby późniejszą lekturę, ujawniałyby jego własną niezręczność, oszustwa czy zarozumiałość. Jeżeli poprawia swój tekst, nie robi tego na bieżąco, ale przy ponownym odczytaniu tekstu, relacjonując kolejnego dnia to, co nie udało się poprzedniego. Obecnie owa skromność autorska i odroczenie w czasie poprawek nie ma racji bytu: autor posługujący się komputerem poprawia na bieżąco tekst, który przez cały czas jest czystopisem, nie nosi bowiem śladów swoich przekształceń. Krytyka genetyczna nic na tym nie zyskuje, ponieważ nadal brakuje nam zapisu kolejnych etapów pracy autora. Warto jednak pamiętać, że możliwość redagowania tekstu na bieżąco za pomocą klawiatury, nie zaś w ciszy w głowie, daje autorowi większą nad nim kontrolę i jest ogromnym ułatwieniem. Niemniej ta łatwość modyfikacji tekstu może stanowić zagrożenie dla uczciwości dziennika, rodząc pokusę, by poprawić wcześniejsze wpisy. Ale jaki diarysta, godny tego miana, zniweczyłby w ten sposób swój projekt?

Genetycy nie mają zatem możliwości prześledzenia procesu powstawania dziennika na podstawie pozostawionych przez ów proces śladów, ponieważ ta-

$14 \mathrm{Ph}$. Lejeune, Philippe de Noircarmes, diariste minute, tekst dostępny online na stronie www.autopacte.org.

15 O. Donnat, Les Pratiques culturelles des Français à l'ère numérique, Paris 2009, s. 202.

16 Ph. Lejeune, „Cher écran...”. Journal personnel, ordinateur, Internet, Paris 2000. Pierwszy rozdział tej książki - po nieznacznych skrótach - ukazał się w przekładzie polskim; zob. Ph. Lejeune, „Drogi ekranie...” Dziennik osobisty i komputer [w:] idem, „,Drogi zeszycie...", ,,drogi ekranie...", s. 298-325. 
kimi śladami nie dysponują. Szukając przed-tekstu dla dziennika, mogą jednak skorzystać z dwóch źródeł, znacząco od siebie różnych. Pierwsze to analiza intertekstualna. Bardzo często zdarza się, że dziennik odwołuje się do innych tekstów, czasem nie mówiąc tego wprost, czasem cytując je bezpośrednio. Niektóre rodzaje dzienników, np. dość powszechne dzienniki lektur, opierają się wręcz całkowicie na cytacie i komentarzu, otwierając szerokie pole do analizy konsumpcji kulturalnej autora. Jego biblioteka staje się w takim wypadku ogromnym przed-tekstem. Dziennik lektur jest zresztą gatunkiem samym w sobie, w tym sensie, że poza zapisem daty nie musi zawierać żadnego oryginalnego tekstu, a może być jedynie mozaiką różnych cytatów. Taki dziennik prowadziła przykładowo Anne Frank - ukazał się on w 2004 roku. Dzięki niemu wiemy, że inspiracją dla dziennika osobistego, którego pisanie Frank rozpoczęła we wrześniu 1942 roku, była seria powieści dla młodzieży wydanych przez Cissy van Marxveldt. Do bohaterów tej właśnie serii Frank adresowała swoje osobiste wpisy $^{17}$. Bardzo często diaryści, zwłaszcza gdy są jednocześnie pisarzami, są też wielkimi czytelnikami. Cytaty, ponowne użycie motywów, aluzje wszelkiego typu, czasem wręcz plagiaty, dość powszechne w dziennikach z podróży, dostarczają bogatego materiału do badań genetycznych.

Ale nie zatrzymujmy się w pół drogi. Głównym intertekstem dla dziennika jest oczywiście korespondencja. Listy otrzymane i wysłane, które mogą być powielane $\mathrm{w}$ całości, cytowane lub komentowane, podobnie jak listy niewysłane, stanowią niemal integralną część tekstu dziennika. Odsyłam w tym względzie do niedawnej pracy Françoise Simonet-Tenant, która bada paralelizmy i obszary wspólne obu praktyk pisarskich ${ }^{18}$. Wystarczą dwa przykłady. Między 8 maja 1781 roku a 3 czerwca 1782 roku przebywający na placówce dyplomatycznej w Ratyzbonie markiz de Bombelles przeżywał rozłąkę z żoną i synem, którzy pozostali na dworze w Wersalu. Prowadził, z myślą o zaledwie rocznym synu, drobiazgowy dziennik i jednocześnie regularnie pisał płomienne i świetnie udokumentowane listy do żony ${ }^{19}$. Wydawcy dziennika, którzy nie znali korespondencji, okroili go z większości osobistych ustępów. Z kolei wydawca listów, które ukazały się ostatnio, nie miał dostępu do integralnego tekstu dziennika. Zainteresowanych tematem wzajemnego uzupełniania się dzienników i korespondencji odsyłam również - i to jest drugi przykład - do znajdującego się w Bibliotece Genewskiej zbioru niewydanej korespondencji Henriego Frédérica Amiela, 6 tys. listów, co daje 24 tys. stron,

17 G. van der Stroom, Qui est la „Kitty” d'Anne Frank?, „La Faute à Rousseau”, czerwiec 2000, nr 24, s. 64-65.

18 F. Simonet-Tenant, Journal personnel et correspondance (1785-1939) ou les affinités électives, Louvain-la-Neuve, 2009.

19 Marquis de Bombelles, Journal, t. I: 1780-1784, oprac. J. Grassion, F. Durif, Genewa 1977; Marquis et Marquise de Bombelles, „Que je suis heureuse d'être ta femme”, Lettres intimes 1778-1782, oprac. É. Lever, Paris 2009. 
dzięki którym oprócz głosu Amiela mamy szansę usłyszeć głosy niektórych z jego przyjaciółek. Dodajmy, że jest to pozostałość całości, która liczyła bez wątpienia 30 tys. listów wysłanych i 20 tys. otrzymanych ${ }^{20}$. Wobec tak ogromnego materiału epistolarnego 12 gigantycznych skądinąd tomów dziennika wydaje się niczym. Zbiory tego typu zmuszają nas zatem do przedefiniowania nie tylko rozróżnień między gatunkami, ale także do przemyślenia całego projektu badań z zakresu krytyki genetycznej. Nie chodzi już bowiem o ustalenie, co jest przed-tekstem, a co dziełem, a o postrzeganie całości owych prywatnych praktyk piśmiennych jako modulacji i deklinacji tego samego tekstu mającego wiele wymiarów.

Drugie źródło, które pozwala podjąć temat genezy w wypadku dziennika, określiłbym jako „ekstratekstualne”, są to bowiem nietekstowe zasoby zewnętrzne. Zebranie wszystkich informacji niezbędnych do ustalenia odniesienia tekstu, zazwyczaj w postaci przypisów, jest zadaniem godnego tego miana wydania krytycznego. Przynajmniej raz zdarzyło mi się, że owo odniesienie, choć nietekstowej natury, istniało w sposób umożliwiający przeprowadzenie porównania $\mathrm{z}$ tekstem dziennika ${ }^{21}$. Uznajmy, że przypadek jest wyjątkowy. 5 września 1950 roku z czystej złośliwości Pierre Sipriot zarejestrował trwającą około 12 minut prywatną rozmowę między nieświadomymi niczego Paulem Léautaudem i Julienem Bendą, którzy przybyli do studia radiowego, by udzielić wywiadu - każdy z osobna. Tego samego wieczoru Léautaud zrelacjonował rozmowę w swoim dzienniku. Znajduje się ona w ostatnim tomie tegoż, wydanym w 1964 roku. Porównanie obu zapisów stanowi nie lada gratkę. Oprócz deformacji w wymiarze tekstowo-informacyjnym, których można było się spodziewać, zaskakuje odkrycie, że choć rozmowa była - o ile nie przed-tekstem - to przynajmniej przedmiotem zapisu w dzienniku, to ów w niektórych wypadkach był przed-tekstem do rozmowy. Dyskutując z Bendą, Léautaud posługuje się formułami ze swojego dziennika, zaczerpniętymi bez wątpienia z innych rozmów. Między zarejestrowaną konwersacją, korespondencją a dziennikiem tekst krąży w taki sposób, że nie wiadomo, co jest „przed" a co „po"...

\section{Geneza w czasie}

Zostawmy na chwilę zagadnienie pojedynczego dnia i odpowiadającego mu wpisu i zajmijmy się dziennikiem w jego ciągłości, obejmującej, jeżeli nie całość, to przynajmniej jej sporą część. Chodzi tym razem o zbadanie genezy... ewolucji dziennika, uzyskanie odpowiedzi na pytanie, jak dokonuje

20 L. Vannieuwenborgh, Amiel écrivait aussi des lettres..., „La Faute à Rousseau”, październik 2003, nr 34, s. 39-40.

${ }_{21} \mathrm{Ph}$. Lejeune, Un brin de causette: Benda, Léautaud [w:] La Conversation. Un art de l'instant, red. G. Cahen, Mutations, vol. 182, Paris 1999, s. 34-57. 
się jego przeobrażanie w czasie. Takie badanie zakłada przeprowadzenie na początku precyzyjnego opisu morfologicznego dziennika, czegoś, co nazywam ,analizą rytmu”. Przedstawiłem ten program w Moi des demoiselles i w Signes de vie ${ }^{22}$, ale właściwie nie miałem dotąd możliwości, by go zastosować. Pomysł polega, w wymiarze ilościowym, na obserwacji długości wpisów i ich rozkładu w czasie, a w wymiarze treściowym - na identyfikacji spójnych elementów (stałych motywów, pojawiających się i znikających tematów) oraz sposobu ich przeplatania się. Zazwyczaj dzienniki cechuje regularność i autoimitacja, wszelka nieregularność czy odstępstwo od określonego systemu nieregularności stanowią raczej ewenement. Tego typu badania morfologiczne byłyby wstępem do refleksji stricte ,genetycznej”. Mogłyby również prowadzić do stworzenia typologii dzienników. Na razie jednak niewielu badaczy poszło tym śladem. Wśród tych nielicznych jest przykładowo Stéphane Roche, który w swojej pracy próbował sformalizować rytm dziennika Charles'a Julieta $^{23}$. Póki co są to zatem niezbadane obszary i trudno nawet jednoznacznie stwierdzić, czy przynależą do dziedziny krytyki genetycznej.

Dodam jeszcze, pozostając w temacie genezy rozpatrywanej przez pryzmat czasu, choć zmieniając nieco jego kontekst, że swego czasu miałem możliwość obserwować pierwsze doświadczenia z prowadzeniem dziennika pewnej dziewczynki, Ariane Grimm ${ }^{24}$, od niepowodzeń jej prób w wieku 7 lat, po początek ,prawdziwego” dziennika, gdy miała 10 lat. Wydaje mi się, że to, co pozwoliło jej w końcu odnieść w tym względzie sukces, to eksperymentowanie $\mathrm{z}$ tożsamością narracyjną w fikcji. Ale analiza takich pierwszych prób jest również na razie słabo rozwiniętą gałęzią krytyki genetycznej.

\section{W kierunku autobiografii}

Opuszczając stopniowo domenę samego dziennika, odnajdujemy coraz więcej typowych działań z zakresu krytyki genetycznej, takich, do jakich przyzwyczaiły nas analizy dzieł autobiograficznych.

$\mathrm{Na}$ granicy między dziennikiem a autobiografią sytuuje się zapis refleksji nasuwających się po przeczytaniu wpisów z przeszłości ${ }^{25}$. Może on odgrywać dwie funkcje, z czego pierwsza ma jeszcze charakter dialogu z tekstem i z sa-

22 Por. Le Moi des demoiselles, Paris, 1993, w szczególności s. 66-67, oraz Continu et discontinu [w:] Signes de vie, Paris 2005, s. 78-82. Drugi z wymienionych tekstów posiada polskie thumaczenie, zob. Ph. Lejeune, Ciagłość i nieciagłość. Dziennik jako seria datowanych śladów [w:] idem, „Drogi zeszycie...”, „, drogi ekranie...”, s. 46-62.

23 S. Roche, Le rythme du journal, ,La Faute à Rousseau”, luty 2001, nr 26, s. 59-61; por. również Le rythme du journal d'Eugénie de Guérin, „L'Amitié Guérinienne”, maj 2004, nr 183, s. 13-36.

${ }^{24} \mathrm{Ph}$. Lejeune, Le journal d'Annick, 7 ans et demi, ,Trames” (CRDP de Haute-Normandie) $2005 \mathrm{nr}$ 12: Éducations féminines, s. 85-100.

25 Idem, Relire son journal [w:] idem, Pour l'autobiographie, Paris 1998, s. 226-228. 
mym sobą, druga jest już czysto dokumentacyjna. Diarysta prowadzi dziennik po to, by go później przeczytać. Pisze go, by zachować w pamięci sprawy i chwile, ale również by - kiedyś, później - móc ocenić przeszłość i to, jak się potoczyła. Wzmianka o takim odczytaniu może się pojawić w dalszej części dziennika lub zaistnieć w formie notatek (datowanych) przypisanych bezpośrednio do określonych ustępów. Najbardziej spektakularne przykłady takich komentarzy autorskich do wpisów z przeszłości, swoistych rozliczeń z samym sobą, znajdujemy w XIX wieku w dziennikach Stendhala, Marie Bashkirtseff, Pierre'a Louÿsa i Catherine Pozzi. Z reguły przebijają z nich irytacja lub złość, może dlatego, że aprobata czy melancholia, uczucia z pewnością dużo powszechniejsze przy lekturze wpisów, nie rodzą takiej potrzeby uwieczniania ich. Wystarczy czerwona kredka, jak u Jules'a Micheleta, który czytając systematycznie swój dziennik, podkreślał całe ustępy, jakby chcąc powiedzieć: „Przejrzałem to”. Dlatego zapewne komentarze autorskie, zwłaszcza do dzienników z okresu młodości, zazwyczaj są pełne irytacji. Czytelnikowi, który nie jest autorem dziennika, może się to wydać niekiedy przejawem naiwności, jaki sens ma bowiem atakowanie wersji samego siebie z przeszłości? Ale nie sposób opowiadać się po żadnej stronie w tych „domowych” sporach prowadzonych przez ja ze swoimi fantomami. Mamy przed sobą bowiem tekst będący palimpsestem, sytuujący się na pograniczu autobiografii. Ta późniejsza glosa, opatrzona precyzyjną datą, może stanowić zalążek złożonych konstrukcji, które odnajdujemy choćby u José Cabanisa czy w monumentalnym dziele Claude'a Mauriaca Le Temps immobile.

Wspomniałem również o wpisach powstałych podczas odczytywania dziennika, a pełniących funkcję dokumentacyjną. Mam na myśli indeksowanie, którego ślady znajdujemy na marginesach dziennika Amiela, przygotowującego się w ten sposób do lektury „tematycznej”. Indeksowanie jest pierwszym działaniem redakcyjnym, w tym wypadku przeprowadzonym - jak się wydaje - na użytek własny. Ale czy to samo możemy powiedzieć o przepisywaniu dziennika? Czy autor przepisywałby setki czy tysiące stron lub zlecałby takie zadanie komuś innemu, mając na uwadze wyłącznie siebie? Weźmy przykład dziennika z okresu młodości Pierre'a-Hyacinthe'a Azaïsa. Oryginalny tekst przepadł bezpowrotnie, pozostały dwie kopie, jedna, kaligrafowana, którą sporządził sam autor, i druga, poszerzona (,genetyczna”, odsyłająca do ustępów włączonych przez Azaïsa do wydanych dzieł!), którą zrobiła jego żona. Podobną troskę o przetrwanie tekstu odnajdujemy u quebeckiej pisarki, Henriette Dessaulles, której dziennik z okresu młodości zachował się dzięki własnoręcznej kopii ${ }^{26}$.

Czy da się „kopiować”, nie starając się poprawiać, a przynajmniej wygładzać, czyli tak naprawdę na nowo pisać? I co dzieje się wówczas $\mathrm{z}$ autentycznością śladu? W wypadku przepisywania granica zostaje przekro-

26 H. Dessaulles (1860-1946), Journal, oprac. J.-L. Major, Montréal 1989. 
czona, wracamy do logiki powstawania dzieła przeznaczonego dla odbiorców. Dziennik rękopiśmienny nie jest już punktem docelowym, nietykalnym, ale punktem wyjścia, poprawialnym. Nie sposób ocenić przy Azaïsie czy Henriette Dessaulles skali wprowadzonych zmian, choć prawdopodobnie była to zwykła kosmetyka. Natomiast szerokie pole badawcze otwiera się przed krytykami genetycznymi w przypadku pisarzy takich jak bracia Goncourt, Léon Bloy i André Gide, którzy brali udział w pracach nad mniej lub bardziej skondensowaną, oczyszczoną, ocenzurowaną wersją swoich dzienników, z myślą o ich publikacji. Oczywiście badania tego typu będą możliwe dopiero z chwilą, gdy oryginalne dzienniki staną się dostępne, przy czym nawet wtedy kwestie metodologiczne i deontologiczne pozostaną nierozstrzygalne. Czy dzieło finalne, przygotowane przez tych pisarzy i wydane z myślą o im współczesnych, przedawniło się? Czy to normalne, że znaleźć je można już tylko na rynku wtórnym? Ale jednocześnie, czy to możliwe, że okrojona wersja kładzie się cieniem na publikacji integralnej wersji dziennika, którą moglibyśmy przeczytać z przyjemnością i jednym tchem, gdyby jej typografia i aparat krytyczny nie nosiły śladów dawnych cięć? Tylko wydanie elektroniczne pozwoliłoby, za pomocą jednego kliknięcia, na przełączanie się między oryginalnym dziennikiem, edycją autorską i kombinacją obu.

Przepisywanie posługuje się różnorodnymi strategiami. Przedstawię tu zaledwie dwa przypadki, po to tylko by pokazać, jak szerokie jest to zagadnienie. W 1984 roku Matthieu Galey zachorował na stwardnienie zanikowe boczne. Wiedząc, że umiera, postanowił przygotować wersję swojego dziennika do publikacji. Zmarł w lutym 1986 roku, a jego dziennik, wydany w 1989 roku, mówi wprost o poprawkach, które naniósł w zeszytach z okresu młodości:

Spędziłem kilka dni z sobą... sprzed ponad 30 lat, odszyfrowując swoje zeszyty z tamtego okresu. Głupota i samozadowolenie, którymi odznaczam się w wieku około 21 lat, wywołują u mnie konsternację. Wiem wszystko, pouczam wszystkich, podziwiam tych, którzy na to nie zasługują, a moje słowa świadczą o naiwności i prostactwie. To zaś, co przedstawia prawdziwą wartość, lekceważę i pomniejszam z zasmucającą częstotliwością! W zasadzie wszystko to należałoby wyrzucić. I cały ten czas stracony na miłostkach lub nieukończonych powieściach! Kolumbarium projektów. Spalić to! ${ }^{27}$

To nie tak, że moje osobiste wspomnienia mają jakąś wartość... Lubuję się w nich jednak choćby ze zwykłej kokieterii: dość, by były wystarczająco odległe, a mój obraz wyłaniający się z nich wydaje się korzystniejszy niż ten, który odbija się w lustrze". Pod tą refleksją, którą François-Olivier Rousseau przypisuje swojemu

27 M. Galey, Journal II, 1974-1986, Paris 1989, s. 316 (1 sierpnia 1984 roku). W jednym z przetłumaczonych na język polski szkiców Lejeune'a dziennik Galeya omawiany jest pod innym kątem, komentowane tam są również i cytowane inne jego fragmenty; zob. Ph. Lejeune, Jak kończa się dzienniki [w:] idem, „Drogi zeszycie...”, ,drogi ekranie...”, s. $120-121$. 
Sébastienowi Doré, mógłbym podpisać się osobiście, słowo w słowo. Spędzam bowiem większą część mojego czasu na porządkowaniu notatek sprzed 25 lat. To, kim w nich jestem, nie podoba mi się wcale - głupi, próżny i frywolny kobieciarz, a do tego snob pogardzający innymi - i Bóg mi świadkiem, że wyrzucam całe strony pozbawione jakiejkolwiek wartości, zapomniane miłostki, rozważania filozoficzne i uniesienia sentymentalne, tak banalne, że trudno to wyrazić! - ale sam dystans wystarczy, by ów kontakt z sobą sprawiał mi przyjemnośćc ${ }^{28}$.

Gdy rękopisy Matthieu Galey będą dostępne, będzie można przeanalizować, w jaki sposób poprawił swój wizerunek z okresu młodości, by uczynić go bardziej spójnym z tym, kim stał się w wieku dojrzałym, co stanowi jak najbardziej klasyczną pracę autobiograficzną.

Kolejny przykład, krańcowo różny, dotyczy Anne Frank. Pozwolę sobie odesłać w tym względzie do eseju, który opublikowałem na temat genezy Oficyny ${ }^{29}$. Wiosną 1944 roku Frank, 15-letnia dziewczyna, chciała wykorzystać wpisy ze swojego dziennika, by stworzyć na ich podstawie książkę-świadectwo z zamiarem wydania jej po wyzwoleniu. Moja analiza, podobnie jak te niezbyt liczne dotyczące historii tego tekstu, może być jedynie analizą genetyczną książki wydanej w 1947 roku przez ojca Anne Frank. Jednak ta bezsprzecznie wspaniała wersja jest wynikiem sytuacji, a nie tym, co sama dziewczyna planowała. Śmierć Anne Frank, podobnie jak śmierć pozostałych mieszkańców oficyny, sprawiła, że powstała śmiała publikacja autobiograficzna zabarwiona tragicznie. Trudno nam wyobrazić sobie, że na początku sierpnia 1944 roku, tuż przed zatrzymaniem, Anne myślała raczej o powieści, której bohaterowie nosiliby fikcyjne imiona, podobnie, że forma, którą Anne wybrała dla przepisanego dziennika, była dość konwencjonalną formą powieści epistolarnej albo że Anne wahała się nad sposobem przedstawienia relacji z Peterem. Czy jednak po wojnie wydałaby taką książkę? Analiza genetyczna publikacji z 1947 roku uwzględnia i jednocześnie fałszuje analizę genetyczną, częściowo opartą na przypuszczeniach, książki, którą planowała stworzyć Anne Frank.

Niezależnie od rodzaju przepisania i cenzury, którą autorzy stosują w swoich dziennikach, pojawia się pytanie, czy możliwość przyszłej publikacji nie wpływa na sposób pisania dziennika, sprawiając, iż pewne upiększenia i wygładzenia zostają wykonane zawczasu. Dotyczy to zwłaszcza dzienników publikowanych w formie „felietonów”, w niewielkim odstępie czasu od ich powstania, jak to było w wypadku Renauda Camusa czy Pascala Sevrana. Docieramy tu do kolejnego interesującego zjawiska, do dzienników publiko-

28 M. Galey, op.cit., s. 380 (27 sierpnia 1985 roku).

$29 \mathrm{Ph}$. Lejeune, Comment Anne Frank a réécrit le journal d'Anne Frank [w:] idem, Les Brouillons de soi, Paris, 1998, s. 331-365 (wyd. pol: idem, W jaki sposób Anne Frank napisała na nowo dziennik Anne Frank, przeł. M. i P. Rodakowie [w:] idem, ,,Drogi zeszycie...,, „,drogi ekranie...”, s. 223-267). Tekst polski zawiera fragmenty nieobecne w publikacji francuskiej, dopisane przez autora dla potrzeb thumaczenia polskiego i angielskiego. 
wanych w internecie. Od kilku lat BnF, we współpracy z Association pour l'Autobiographie (APA), archiwizuje te teksty, które inaczej przepadłyby bezpowrotnie ${ }^{30}$. „Webuscrits” nie noszą wprawdzie śladów swojego powstawania, ale pozwalają na zapoznanie się z ich recepcją dzięki przestrzeni dialogu, która otacza i stymuluje tego typu produkcję. Być może nawet w przyszłości „krytyka recepcji” stanie się gałęzią krytyki genetycznej, analizującą oddziaływanie odbioru tekstu na akt jego powstawania w praktykach o charakterze społecznościowym?

\section{Geneza wydawnicza}

Zatrzymam się na tym etapie $\mathrm{w}$ niniejszej analizie. Warto jeszcze zastanowić się nad opracowaniem historii wydań pośmiertnych. Ale jest to odrębne zagadnienie, równie szeroko zakrojone i kluczowe z punktu widzenia recepcji dziennika i upowszechnienia jego modeli. Dodatkowo podlega ono innej logice analizy, ponieważ uwzględnia przynajmniej dwóch autorów: autora dziennika i autora (lub autorów) wydań. Powrót do oryginalnego rękopisu po okrojonych lub błędnych wydaniach wiąże się w sposób oczywisty z dwoma aspektami: powstaniem wiernego oryginałowi wydania (taki sam problem pojawia się przy przygotowywaniu publikacji niewydanych jeszcze dzienników) oraz analizą pierwszego niedokładnego wydania. Jednym z większych wyzwań, przed którymi stanie nowy wydawca, będzie odpowiedź na pytanie, jak nie przeciążyć przywoływanego do życia tekstu nadmiarem wyjaśnień, czyli wykonanie koniecznej pracy w zakresie transmisji tekstu i pozostanie przy tym dyskretnym.

przet. Lucyna Mazur

Pierwodruk: Philippe Lejeune, Le journal: genèse d'une pratique, „Genesis” 2011, nr 32: Journaux personnels, s. 29-42.

\section{Bibliografia}

Dantzig Ch., Dictionnaire égoïste de littérature française, Paris 2005.

Diaz J.-L., Quelle génétique pour la correspondance?, „Genesis” 1999, nr 13.

Donnat O., Les Pratiques culturelles des Français à l'ère numérique, Paris 2009.

Genin Ch., L'archivage de l'intime en ligne, „Bibliothèque(s)” 2009, nr 47-48.

30 Ch. Genin, L'archivage de l'intime en ligne, „Bibliothèque(s)”, grudzień 2009, nr $47-48$, s. 50-52. 
Lejeune Ph., Azaïs et le journal-œuvre, tekst dostępny online na stronie www.autopacte.org.

Lejeune Ph., ,, Cher écran... ”. Journal personnel, ordinateur, Internet, Paris 2000.

Lejeune Ph., Comment Anne Frank a réécrit le journal d'Anne Frank [w:] Les Brouillons de soi, Paris 1998.

Lejeune Ph., Continu et discontinu [w:] idem, Signes de vie, Paris 2005.

Lejeune Ph., „Drogi zeszycie...”, „,drogi ekranie”. O dziennikach osobistych, przeł. A. Karpowicz, M. i P. Rodakowie, Warszawa 2010.

Lejeune Ph., Le journal d'Annick, 7 ans et demi, ,Trames” (CRDP de Haute-Normandie) 2005, nr 12: Éducations féminines.

Lejeune Ph., Le Moi des demoiselles, Paris 1993.

Lejeune Ph., Les Brouillons de soi, Paris 1998.

Lejeune $\mathrm{Ph}$., Philippe de Noircarmes, diariste minute, tekst dostępny online na stronie www.autopacte.org.

Lejeune Ph., Relire son journal [w:] idem, Pour l'autobiographie, Paris 1998.

Lejeune Ph., Un brin de causette: Benda, Léautaud [w:] La Conversation. Un art de l'instant, red. G. Cahen, Mutations, vol. 182, Paris 1999.

Lejeune Ph., Bogaert C., Un journal à soi. Histoire d'une pratique, Paris 2003.

Lejeune Ph., Bogaert C., Un journal à soi (ou la passion des journaux intimes), Lyon 1997.

Roche S., Le rythme du journal, „La Faute à Rousseau” 2001, nr 26.

Roche S., Le rythme du journal d'Eugénie de Guérin, „L'Amitié Guérinienne” 2004 nr 183.

Stroom G. van der, Qui est la „Kitty” d'Anne Frank?, „La Faute à Rousseau” 2000, $\mathrm{nr} 24$.

Vannieuwenborgh L., Amiel écrivait aussi des lettres..., „La Faute à Rousseau” 2003, nr 34. 